Фармацевтичний менеджмент, маркетинг та логістика

Pharmaceutical management, marketing and logistics

Рекомендована д. фрармац. наук, проф. В. В. Трохимчуком

УДК 615.252.349.7:339.138

DOI 10.11603/2312-0967.2017.3.8030

\title{
МАРКЕТИНГОВЕ ОБҐРУНТУВАННЯ ДОЦІЛЬНОСТІ РОЗРОБКИ НОВОГО ЛІКАРСЬКОГО ПРЕПАРАТУ НА РОСЛИННІЙ ОСНОВІ ДЛЯ ЛІКУВАННЯ ЦУКРОВОГО ДІАБЕТУ ДРУГОГО ТИПУ
}

\author{
(ст. Є. Колісник, О. А. Рубан, А. Б. Ольховська \\ Національний фрармацевтичний університет, Харків \\ kolisnyktatyana@gmail.com
}

\begin{abstract}
Мета роботи. Обґрунтувати у контексті маркетингу доцільність створення нового фрармацевтичного препарату на основі субстанції рослинного походження для лікування цукрового діабету другого типу.

Матеріали і методи. У роботі використано маркетинговий метод, методи моніторингу, логічного узагальнення, угрупування та грасрічний метод дослідження.

Результати й обговорення. Проведено порівняльний аналіз асортименту та економічної доступності пероральних цукрознижувальних засобів синтетичного і рослинного походження, представлених на фрармацевтичному ринку України. Встановлено, що найширшими асортиментом та економічною доступністю серед синтетичних засобів характеризуються препарати бігуанідів та похідних сульфонілсечовини. Порівняно 3 синтетичними засобами лікарські препарати рослинного походження є доступнішими, втім їх асортимент є дуже обмеженим.

Висновки. За результатами проведених досліджень обґрунтовано перспективність розробки нового вітчизняного препарату на рослинній основі у твердій дозованій фрормі для лікування цукрового діабету другого типу.
\end{abstract}

Ключові слова: маркетингові дослідження; цукровий діабет другого типу; пероральні цукрознижувальні засоби; фармацевтичний ринок України.

Вступ. Цукровий діабет (ЦД) являє собою тяжке метаболічне захворювання, яке характеризується хронічною гіперглікемією - стійким підвищенням рівня глюкози у сироватці крові. Неконтрольована гіперглікемія викликає серйозні порушення роботи багатьох органів та систем організму. Найбільш частими ускладненнями цукрового діабету є ураження серця, кровоносних судин, очей, нирок та нервів [1].

ЦД є однією з найпоширеніших неінфекційних хвороб, а його ускладнення - основною причиною смертності у більшості країн світу. За оцінкою Міжнародної діабетичної фредерації (International Diabetes Federation; надалі IDF) у 2015 році чисельність хворих на ЦД у віці від 20 до 79 років становила близько 415 млн (8,8 \% від загальної популяції), а кількість випадків смерті, пов'язаних із діабетом, сягнула майже 5 млн. Показники поширеності ЦД різняться залежно від регіону: від 3,2 \% у країнах Афррики до 12,9 \% у Північній Америці та Карибських островах. В Європі розповсюдженість ЦД складає 9,1\%, коливаючись від 5,3 \% в Ірландії до 13,9 \% у Мальті [2]. В Україні, за даними Центру медичної статистики Міністерства охорони здоров'я, станом на 1 січня 2016 року зареєстровано 1223604 хворих на ЦД [3]. Втім за підрахунками фрахівців IDF кількість осіб в Україні, що страждають на діабет, перевищує 2,7 млн, тобто більше половини з них має недіагностований діабет [2].
У більшості хворих (до 90 \%) виявляють ЦД 2 типу. У виникненні і прогресуванні даного типу діабету важливу роль відіграє порушення специфічної реакції клітин-мішеней на дію гормону інсуліну, внаслідок чого погіршується засвоєння глюкози м'язами і жировою тканиною та підвищується концентрація глюкози в крові. 3 метою корекції цього стану застосовують пероральні цукрознижувальні засоби (ПЦЗ), які підвищують чутливість клітин периферичних тканин до інсуліну та/або стимулюють його секрецію підшлунковою залозою [4].

Наразі світовий фрармацевтичний ринок щорічно поповнюється як генеричними, так і новими оригінальними ПЦз. Однак жоден 3 існуючих препаратів для лікування ЦД 2 типу не позбавлений певних побічних есректів, що значно обмежують можливість тривалого застосування та контролю глікемії. Порівняльну характеристику основних класів ПЦЗ подано в таблиці 1.

На жаль, існуючі синтетичні ПЦЗ не вирішують глобальної ситуації, що склалася із ЦД 2 типу. Насамперед, це пояснюється прогресуючим характером захворювання, що вимагає інтенсисрікації гіпоглікемізуючої терапії. Як наслідок, монотерапія синтетичними ПЦЗ характеризується обмеженим терміном ефрективності: згідно з дослідженнями через 3 роки після діагностування ЦД 2 типу комбінованої терапії потребують 45 \% пацієнтів, а вже через 9 ро-

ISSN 2312-0967. Фармацевтичний часопис. 2017. № 3 
Фармацевтичний менеджмент, маркетинг та логістика Pharmaceutical management, marketing and logistics

Таблиця 1. Порівняльна характеристика основних класів пероральних цукрознижуваних засобів

\begin{tabular}{|c|c|c|}
\hline $\begin{array}{l}\text { Основні представники } \\
\text { міжнародною } \\
\text { непатентованою } \\
\text { назвою, представлені } \\
\text { на ринку України } \\
\end{array}$ & Переваги & Недоліки та найчастіші побічні ефеекти \\
\hline 1 & 2 & 3 \\
\hline \multicolumn{3}{|c|}{ Препарати сульфоонілсечовини другого та третього покоління } \\
\hline $\begin{array}{l}\text { Глібенкламід } \\
\text { Гліпізид } \\
\text { Гліклазид } \\
\text { Глімеперид }\end{array}$ & $\begin{array}{ll}\text { - } & \text { швидкий початок дії; } \\
\text { - } & \text { не впливають на кров'яний тиск; } \\
\text { - } & \text { не впливають на рівень } \\
& \text { ліпопротеїнів низької щільності; } \\
\text { - } & \text { порівняно з меторорміном нижчий } \\
& \text { ризик розвитку шлунково-кишкових } \\
& \text { порушень. }\end{array}$ & $\begin{array}{ll}\text { - } & \text { ризик розвитку гіпоглікемії, особливо при } \\
& \text { порушенні функції нирок; } \\
\text { - } & \text { збільшення маси тіла; } \\
\text { - } & \text { зниження ефрективності при тривалому } \\
& \text { застосуванні }\end{array}$ \\
\hline \multicolumn{3}{|c|}{ Бігуаніди } \\
\hline Меторормін & $\begin{array}{ll}\text { - } & \text { приймання препарату не } \\
& \text { асоційоване із збільшенням маси } \\
& \text { тіла; } \\
\text { - } & \text { низький ризик розвитку гіпоглікемії; } \\
\text { - } & \text { зменшує рівень ліпопротеїнів } \\
& \text { низької щільності; } \\
\text { - } & \text { зменшує рівень тригліцеридів; } \\
\text { - } & \text { не впливає на кров'яний тиск }\end{array}$ & $\begin{array}{l}\text { - } \\
\text { ризик розвитку шлунково-кишкових } \\
\text { порушень, зокрема діареї, нудоти, } \\
\text { абдомінальних спазмів; } \\
\text { - } \\
\text { ризик розвитку потенційно смертельного } \\
\text { лактацидозу в осіб із супутніми нирковою } \\
\text { хворобою помірного або тяжкого ступеня, } \\
\text { гострим або хронічним метаболічним } \\
\text { ацидозом, серцевою недостатністю, } \\
\text { захворюваннями печінки, алкоголізмом } \\
\text { та ін.; } \\
\text { - } \\
\text { підвищений ризик розвитку дефріциту } \\
\text { вітаміну } \text { В }_{12} ; \\
\text { - металевий присмак у роті }\end{array}$ \\
\hline \multicolumn{3}{|c|}{ Інгібітори альфра-глюкозидази } \\
\hline Воглібоза & $\begin{array}{ll}\text { - } & \text { місцева дія (інгібування } \\
\text { розщеплення складних вуглеводів } \\
\text { і всмоктування моноцукрів у тонкій } \\
\text { кишці); } \\
\text { - } \\
\text { порівняно з препаратами } \\
\text { сульфонолсечовини нижчий ризик } \\
\text { розвитку гіпоглікемії; } \\
\text { - } \\
\text { приймання препаратів даної групи } \\
\text { не асоційоване із збільшенням } \\
\text { маси тіла; } \\
\text { - } \\
\text { не впливають на рівень } \\
\text { ліпопротеїнів низької щільності. }\end{array}$ & $\begin{array}{ll}\text { - } & \text { порівняно з іншими препаратами менша } \\
& \text { ерективність щодо зниження глікованного } \\
& \text { гемоглобіну крові; } \\
\text { - } & \text { підвищений ризик шлунково-кишкових } \\
& \text { порушень порівняно з іншими } \\
& \text { препаратами, окрім метфрорміну }\end{array}$ \\
\hline \multicolumn{3}{|c|}{ Тіазолідиндіони } \\
\hline Піоглітазон & $\begin{array}{ll}\text { - } & \text { низький ризик розвитку гіпоглікемії; } \\
\text { - } & \text { призводять до невеликого } \\
& \text { підвищення рівня ліпопротеїнів } \\
& \text { високої щільності; } \\
\text { - } & \text { знижують рівень тригліцеридів }\end{array}$ & $\begin{array}{ll}\text { - } & \text { підвищений ризик розвитку серцевої } \\
& \text { недостатності; } \\
\text { - } & \text { збільшення маси тіла; } \\
\text { - } & \text { ризик затримки рідини в організмі та } \\
& \text { розвитку набряків; } \\
\text { - } & \text { ризик розвитку анемії; } \\
\text { - } & \text { збільшення рівня ліпопротеїнів низької } \\
& \text { щільності; } \\
\text { - } & \text { прийом пов'язаний із ризиком розвитку } \\
& \text { раку сечового міхура; } \\
\text { - } & \text { при застосуванні препаратів даної групи } \\
& \text { потрібне проведення моніторингу фрункції } \\
& \text { печінки; } \\
\text { - підвищений ризик переломів кінцівок. }\end{array}$ \\
\hline
\end{tabular}

ISSN 2312-0967. Pharmaceutical review. 2017. № 3 
Фармацевтичний менеджмент, маркетинг та логістика

Pharmaceutical management, marketing and logistics

Продовження табл. 1

\begin{tabular}{|c|c|c|}
\hline 1 & 2 & 3 \\
\hline \multicolumn{3}{|c|}{ Інгібітори дипептидилпептидази-4 (DPP-4) } \\
\hline $\begin{array}{l}\text { Саксагліптин } \\
\text { Сітагліптин }\end{array}$ & $\begin{array}{ll}\text { - } & \text { відсутність ризику розвитку } \\
& \text { гіпоглікемії при монотерапії; } \\
\text { - } & \text { не впливають на масу тіла; } \\
\text { - } & \text { характеризуються доброю } \\
& \text { переносимістю }\end{array}$ & $\begin{array}{ll}\text { - } & \text { необхідність корекції дози для пацієнтів } 3 \\
\text { помірним або тяжким порушенням функції } \\
\text { нирок; } \\
\text { - } \\
\text { одночасне прийманя з індукторами } \\
\text { чи інгібіторами цитохрому Р450 ЗА4/5 } \\
\text { (СҮР ЗА4/5) призводить до змінення } \\
\text { концентрації у плазмі крові (саксагліптин); } \\
\text { - } \quad \text { ризик розвитку панкреатиту; } \\
\text { - } \quad \text { ризик розвитку або погіршення наявної } \\
\text { серцевої недостатності; } \\
\text { - } \\
\quad \text { ризик виникнення сильного болю в } \\
\text { суглобах }\end{array}$ \\
\hline \multicolumn{3}{|c|}{ Меглітиніди } \\
\hline Репаглінід & $\begin{array}{l}\text { - } \\
\text { швидка та короткочасна дія, } \\
\text { внаслідок чого може бути } \\
\text { рекомендованим для глікемічного } \\
\text { контролю в окремих випадках } \\
\text { порушення дієти, у пацієнтів } \\
\text { з нерегулярним режимом } \\
\text { харчування або у випадку розвитку } \\
\text { пізньої гіпоглікемії при прийманні } \\
\text { препаратів сульсонілсечовини }\end{array}$ & $\begin{array}{ll}\text { - } & \text { ризик розвитку гіпоглікемії; } \\
\text { - } & \text { прийом асоційований із збільшенням ваги } \\
& \text { тіла; } \\
\text { - } & \text { необхідність частого застосування } \\
& \text { (кількість прийомів є кратною кількості } \\
& \text { прийомів їжі). }\end{array}$ \\
\hline \multicolumn{3}{|c|}{ Інгібітори натрій-глюкозного котранспортеру 2 типу (SGLT2) } \\
\hline Дапагліфлозин & $\begin{array}{ll}\text { - } & \text { відсутність ризику розвитку } \\
\text { гіпоглікемії при монотерапії; } \\
\text { - } \\
\text { - } \\
\text { зменшення ваги тіла; } \\
\text { зменшення серцево-судинної } \\
\text { смертності, загальної смертності } \\
\text { та госпіталізації через серцеву } \\
\text { недостатність у хворих на цукровий } \\
\text { діабет } 2 \text { типу із серцево-судинними } \\
\text { захворюваннями }\end{array}$ & 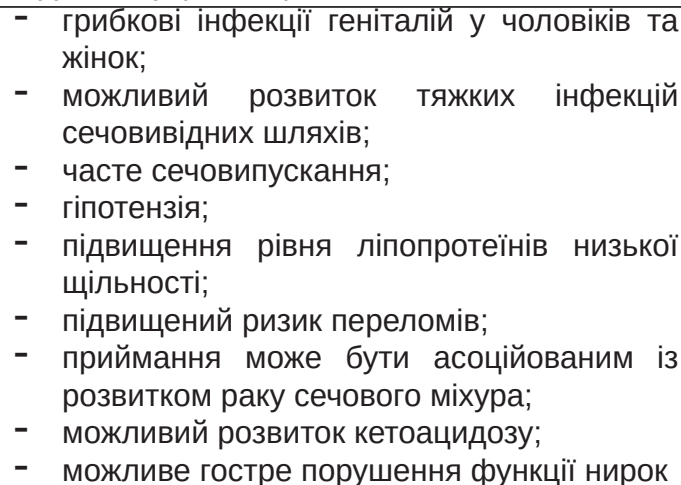 \\
\hline
\end{tabular}

Джерело: складено авторами за матеріалами [5, 6].

ків ця цифра сягає 75 \% [7]. У зв'язку з цим важливу роль у стратегіях глікемічного контролю при ЦД 2 типу відіграє комбінована терапія із застосуванням різних класів ПЦЗ. Саме тому забезпеченість населення лікарськими засобами, що належать до різних класів ПЦЗ, є необхідною передумовою для вибору оптимальної терапії у кожному конкретному випадку.

Перспективним напрямком у підтриманні глікемічного контролю та попередженні розвитку діабетичних ускладнень $€$ включення у схеми лікування хворих на ЦД 2 типу препаратів рослинного походження із гіпоглікемічною активністю. Ці препарати мають високий профріль безпеки при довгостроковому застосуванні та можуть бути ефективними у якості монотерапії на початкових стадіях захворювання або у комбінації із синтетичними ПЦЗ для досягнення глі- кемічного контролю при використанні менших доз останніх [8, 9].

Таким чином, мета даної роботи - обґрунтування доцільності створення нового фрармацевтичного препарату на основі субстанції рослинного походження для лікування ЦД 2 типу. Досягнення поставленої мети передбачало виконання наступних завдань:

1) аналіз асортименту представлених на фрармацевтичному ринку України ПЦЗ синтетичного походження;

2) визначення економічної доступності представлених на фрармацевтичному ринку України синтетичних ПЦЗ;

3) дослідження представленості та економічної доступності на вітчизняному ринку рослинних лікарських засобів гіпоглікемічної дії.

ISSN 2312-0967. Фармацевтичний часопис. 2017. № 3 
Матеріали і методи. У роботі застосовані маркетинговий метод, методи моніторингу, логічного узагальнення, угрупування та графрічний метод дослідження. Об'єктами досліджень слугували зареєстровані в Україні синтетичні пероральні цукрознижувальні препарати, а також лікарські рослинні засоби гіпоглікемічної дії. В якості інорормаційних матеріалів використовувались наступні джерела: Державний реєстр лікарських засобів України [10]; довідник лікарських засобів «Компендіум онлайн» [11]; інтернетресурси з пошуку ліків в аптеках України «GeoApteka» [12] та «Tabletki.ua» [13]; оптові пропозиції лікарських засобів для аптек згідно програмного комплексу «Аптека» [14].

Результати й обговорення. Згідно з Державним реєстром лікарських засобів України станом на І квартал 2017 року зареєстровано 173 торгових найменувань синтетичних ПЦЗ (з урахуванням препаратів, що виробляються в різних дозуваннях та/або лікарських формах). Аналіз за допомогою онлайнсервісів пошуку ліків в аптеках України виявив, що фрактично на вітчизняному фрармацевтичному ринку були представлені лише 101 торгове найменування синтетичних ПЦЗ, більшість з яких склала препарати іноземного виробництва - їх кількість майже у 2 рази перевищувала кількість вітчизняних препаратів (65 та 36 торгових найменувань відповідно). Відповідно до системи Анатомо-терапевтично-хімічної (ATX) класифікації наявні на фрармацевтичному ринку України синтетичні ПЦЗ можуть бути віднесені до декількох груп (рис. 1).

Серед монопрепаратів синтетичного походження найчисельнішою за кількістю торгових найменувань, а також за кількістю представлених міжнародних непатентованих назв (МHН) є група препаратів похідних сульфонілсечовини, що включає препарати другої (глібенкламід, гліквідон, гліклазід) та третьої (глімепірид) генерації. Наступною за кількістю МНH $є$ група інгібіторів DPP-4, яка представлена препаратами ситагліптину та саксагліптину. Інші з перелічених груп монопрепаратів включають лише по одній МНH. Розподіл синтетичних монопрепаратів ПЦЗ вітчизняного та іноземного виробництва за МНH подано на рисунку 2.

Як видно з даних рисунка 2, серед представлених монопрепаратів найбільшу кількість складають торгові найменування метформіну та глімепіриду. Препарати вказаних МНH переважають як серед вітчизняних, так й імпортних засобів, втім чисельність останніх майже в 2 рази є більшою (22 і 12 - для метформіну та 17 і 9 - для глімепіриду). Інші МНН ПЦЗ представлені значно меншою кількістю торгових найменувань; з них препарати гліквідону, ситагліптину, саксагліптину, дапагліфллозину та репаглініду $€$ виключно іноземного виробництва. Лише вітчизняними виробниками представлені препарати воглібози та піоглітазону.

Асортимент комбінованих ПЦЗ синтетичного походження приведено на рис. 3.

Отже, як випливає 3 поданих вище даних, асортимент різних класів синтетичних ПЦЗ на вітчизняному фармацевтичному ринку є вкрай неоднаковим. Широко представленими як іноземними, так і вітчизняними виробниками є препарати бігуанідів та похідних сульсронілсечовини, причому з останніх провідну позицію займають препарати глімепіриду. Препарати інших класів синтетичних ПЦЗ репрезентовані у значно менше.

Поряд з фрізичною доступністю лікарських препаратів, тобто їх наявністю у аптечних закладах, важливим фрактором при виборі оптимальної терапії $€$ спроможність хворих оплачувати необхідне лікування - економічна доступність ліків. Відомо, що чим меншу частку становлять витрати на придбання лікарського препарату в доходах споживачів, тим вище їх економічна доступність.

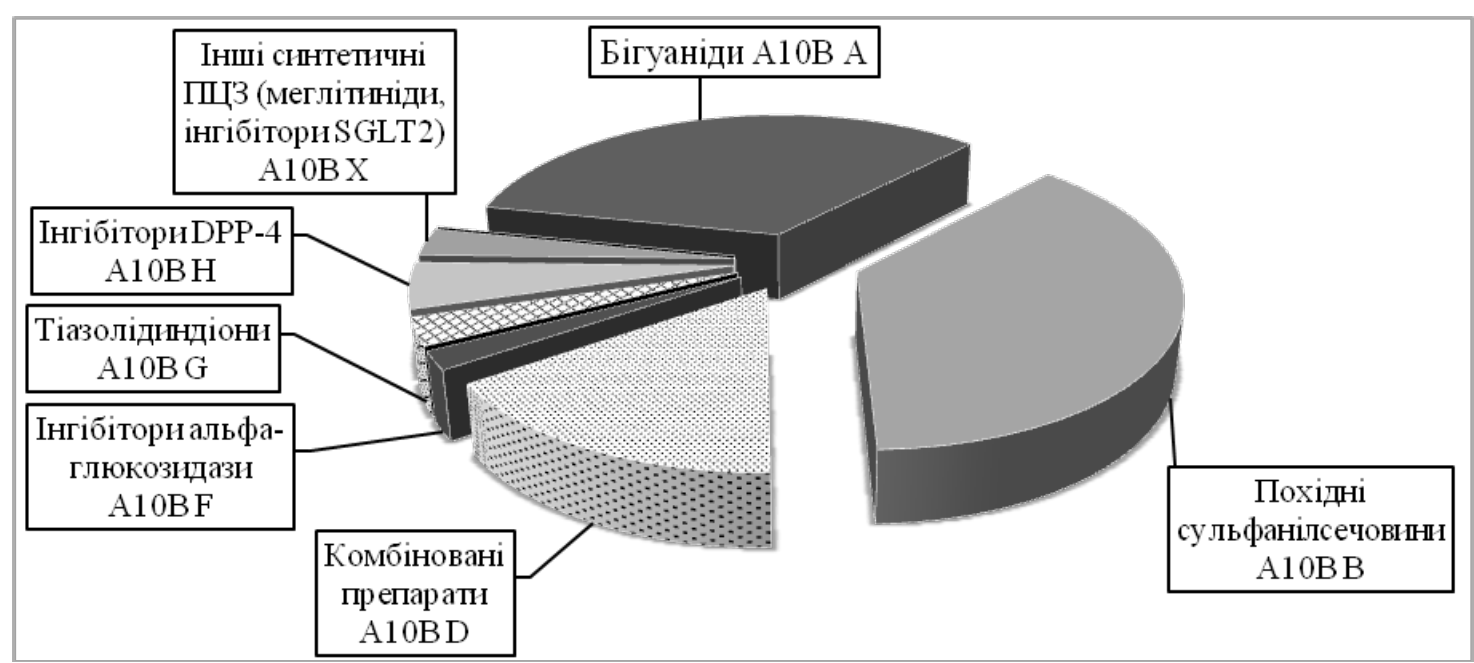

Рис. 1. Структура сегмента синтетичних пероральних цукрознижувальних засобів (із вказанням ATX-коду для кожної групи)

ISSN 2312-0967. Pharmaceutical review. 2017. № 3 
Фармацевтичний менеджмент, маркетинг та логістика

Pharmaceutical management, marketing and logistics

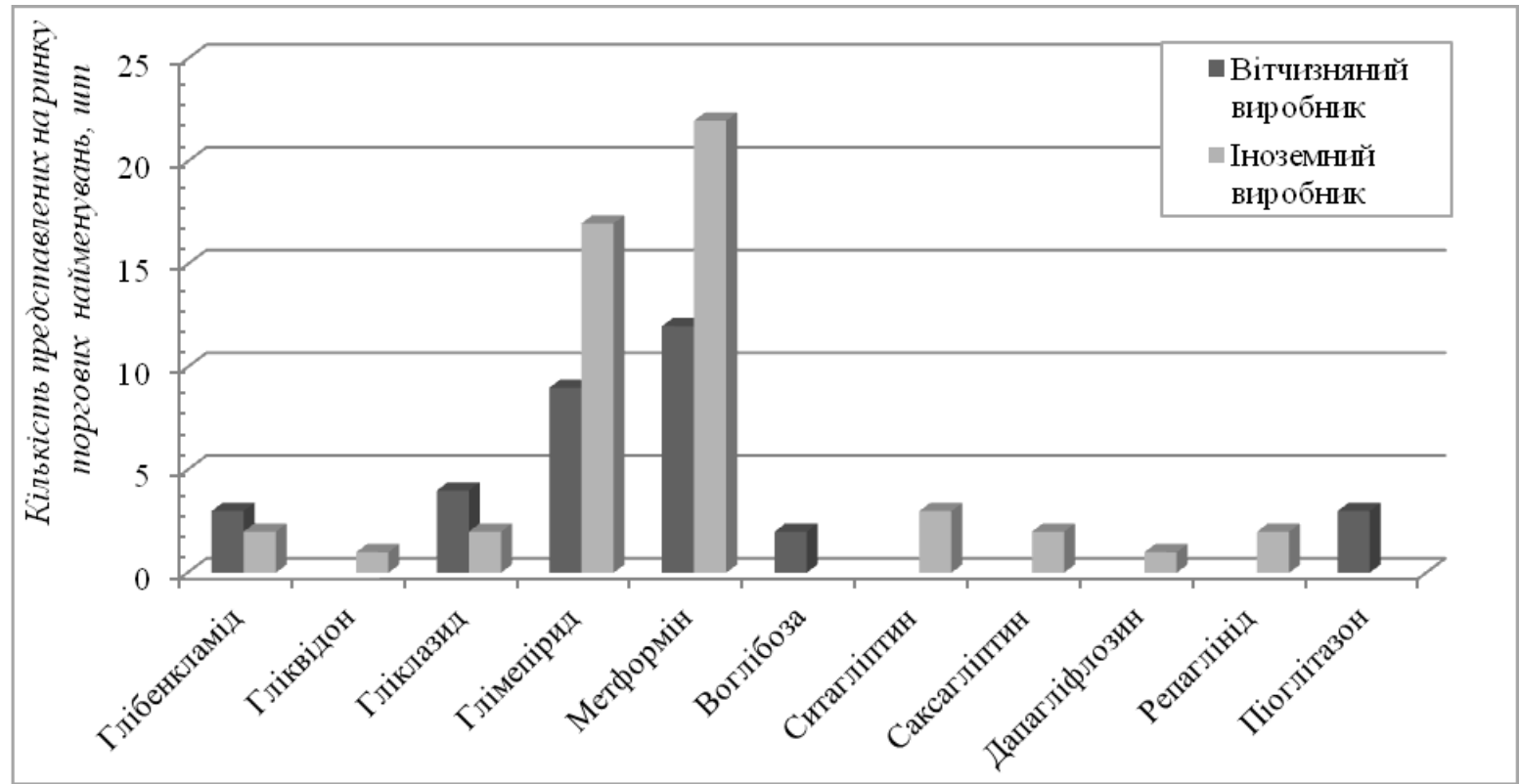

Рис. 2. Розподіл синтетичних монопрепаратів синтетичних пероральних цукрознижувальних засобів за міжнародною непатентованою назвою.

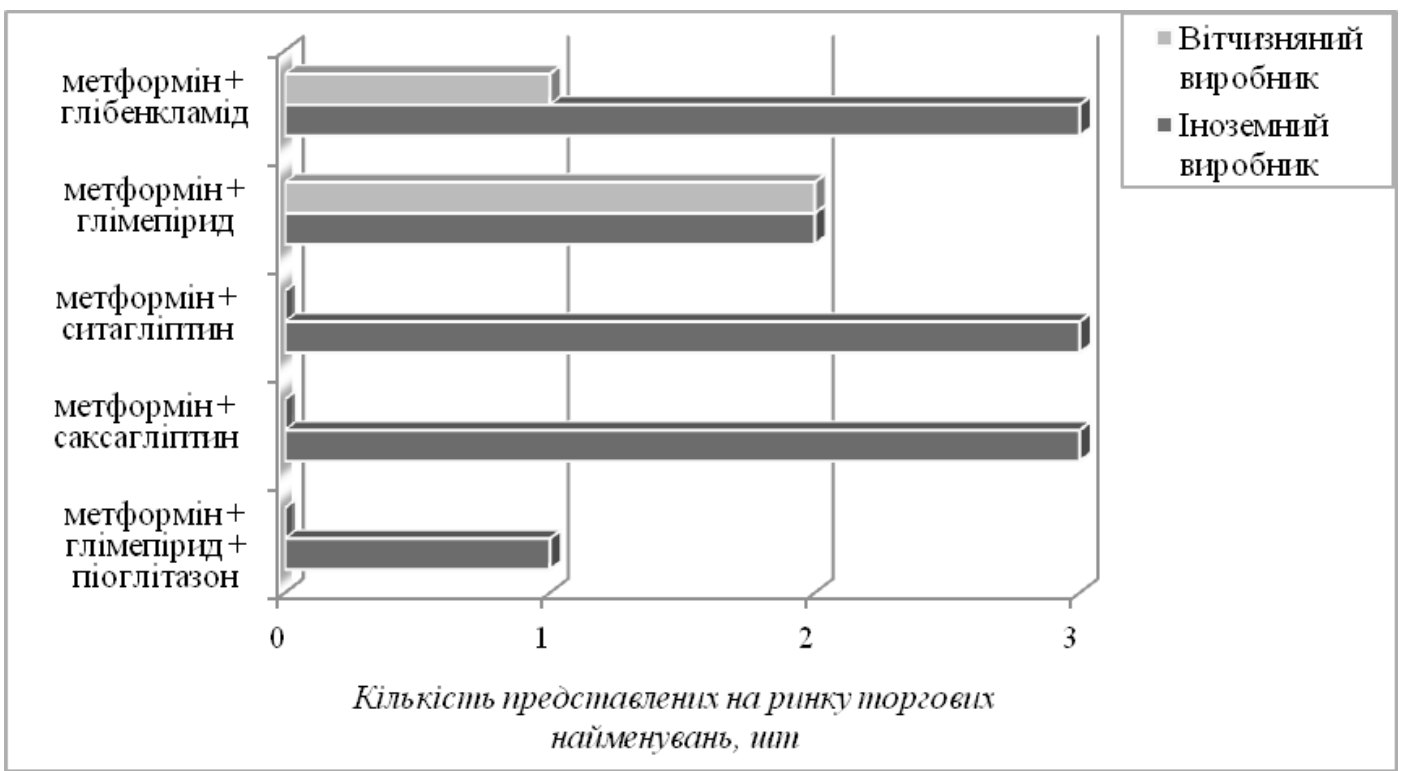

Рис. 3. Асортимент комбінованих пероральних цукрознижувальних засобів синтетичного походження, представлених на фрармацевтичному ринку України.

Для оцінки економічної доступності синтетичних ПЦЗ необхідно було розрахувати вартість одного дня лікування даними препаратами. Для порівняння використовувалася стандартна середня добова доза лікарського засобу - Defined Daily Dose (DDD), яка максимально наближена до реального застосування і введена на підставі практичних рекомендацій і довідкових джерел, даних і рад виробників ліків і клінічного досвіду по використанню лікарських засобів [15]. Результати розрахунків подано в таблиці 2, при цьому для МНH, представлених декількома (або ба- гатьма) торговими найменуваннями, приведені мінімальні та максимальні вартості DDD відповідних дозувань. У разі, якщо на ринку наявні різні за кількістю таблеток упаковки одного і того ж препарату, для порівняння обрана вартість більшої упаковки (з огляду на довготривалість гіпоглікемізуючої терапії при Цд 2 типу, а значить й споживчі вподобання щодо упаковок з більшою кількістю таблеток). У розрахунках використовували середньозважену роздрібну вартість лікарських засобів в Україні за станом на березень 2017 року [11].

ISSN 2312-0967. Фармацевтичний часопис. 2017. № 3 
Фармацевтичний менеджмент, маркетинг та логістика Pharmaceutical management, marketing and logistics

Таблиця 2. Вартість DDD синтетичних пероральних цукрознижувальних засобів на фрармацевтичному ринку України

\begin{tabular}{|c|c|c|c|c|}
\hline $\begin{array}{c}\text { Міжнародна } \\
\text { непатентована } \\
\text { назва } \\
\end{array}$ & Торгове найменування, форма випуску, виробник & $\begin{array}{c}\text { DDD, } \\
\text { мг або } \\
\text { табл. }\end{array}$ & $\begin{array}{c}\text { Вартість } \\
\text { упаковки, } \\
\text { грн } \\
\end{array}$ & $\begin{array}{c}\text { Вартість } \\
\text { DDD, } \\
\text { грн } \\
\end{array}$ \\
\hline 1 & 2 & 3 & 4 & 5 \\
\hline \multicolumn{5}{|c|}{ Похідні сульфронілсечовини } \\
\hline \multirow[t]{2}{*}{ Глібенкламід } & ГЛІБЕНКЛАМІД табл. 5 мг №30, ПрАТ "Технолог", Україна & $10 \mathrm{Mr}$ & 8,26 & 0,55 \\
\hline & МАНІНІЛ ${ }^{\circledR}$ табл. 5 мг №120, БЕРЛІН-ХЕМІ АГ, Німеччина & $7 \mathrm{Mr}$ & 85,22 & 0,99 \\
\hline Гліквідон & $\begin{array}{l}\text { ГЛЮРЕНОРМ }{ }^{\circledR} \text { табл. } 30 \text { мг №60, Берінгер Інгельхайм Еллас } \\
\text { А.Е., Греція }\end{array}$ & $60 \mathrm{Mr}$ & 210,82 & 7,02 \\
\hline \multirow[t]{6}{*}{ Гліклазид } & $\begin{array}{l}\text { ГЛІКЛАЗИД-ЗДОРОВ'Ятабл. } 80 \text { мг №30, ТОВ"Фармацевтична } \\
\text { компанія "Здоров'я", Україна }\end{array}$ & 160 мг & 29,83 & 1,99 \\
\hline & ДІАГЛІЗИД ${ }^{\circledR}$ табл. 80 мг №60, ПАТ "Фармак", Україна & 160 мг & 94,48 & 3,15 \\
\hline & $\begin{array}{l}\text { ДІАЗИД МВ табл. } 3 \text { модифр. вивіл. } 30 \text { мг №60, ТОВ "Фарма } \\
\text { Старт", Україна }\end{array}$ & $60 \mathrm{Mr}^{\star \star}$ & 48,95 & 1,63 \\
\hline & $\begin{array}{l}\text { ДІАГЛІЗИД МR табл. } 3 \text { модифр. вивіл. } 30 \text { мг №60, ПАТ } \\
\text { "Фармак", Україна }\end{array}$ & $60 \mathrm{Mr}^{\star \star}$ & 74,89 & 2,50 \\
\hline & $\begin{array}{l}\text { ДІАГЛІЗИД МR табл. } 3 \text { модиф. вивіл. } 60 \text { мг №30, ПАТ } \\
\text { "Фармак", Україна }\end{array}$ & $60 \mathrm{Mr}^{\star \star}$ & 78,39 & 2,61 \\
\hline & $\begin{array}{l}\text { ДІАБЕТОН }{ }^{\circledR} \text { МR табл. з модифр. вивіл. } 60 \text { мг №30, Лабораторії } \\
\text { Серв'є Індастрі, Франція }\end{array}$ & $60 \mathrm{Mr}^{\star \star}$ & 112,57 & 3,75 \\
\hline \multirow[t]{7}{*}{ Глімепірид } & ДІМАРИЛ ${ }^{\circledR}$ табл. 2 мг №30, ПАТ "Київмедпрепарат", Україна & $2 \mathrm{Mr}$ & 54,73 & 1,82 \\
\hline & $\begin{array}{l}\text { ОЛТАР }{ }^{\circledR} \text { табл. } 2 \text { мг №30, А. Менаріні Манусрактурінг Логістікс } \\
\text { енд Сервісес С.р.Л., Індія/Італія/Італія }\end{array}$ & $2 \mathrm{Mr}$ & 124,64 & 4,15 \\
\hline & ГЛИМАКС ${ }^{\circledR}$ табл. 3 мг №60, ТОВ "КУСУМ ФАРМ", Україна & $2 \mathrm{Mr}$ & 113,76 & 1,26 \\
\hline & АМАРИЛ ${ }^{\circledR}$ табл. 3 мг №30, Санофі-Авентіс С.п.А, Італія & $2 \mathrm{Mг}$ & 160,61 & 3,57 \\
\hline & ГЛИМАКС ${ }^{\circledR}$ табл. 4 мг №60, ТОВ "КУСУМ ФАРМ", Україна & $2 \mathrm{Mг}$ & 162,22 & 1,35 \\
\hline & $\begin{array}{l}\text { ОЛТАР }{ }^{\circledR} \text { табл. } 4 \text { мг №30, А. Менаріні Манусрактурінг Логістікс } \\
\text { енд Сервісес С.р.Л., Індія/Італія/Італія }\end{array}$ & $2 \mathrm{Mr}$ & 232,64 & 3,88 \\
\hline & $\begin{array}{l}\text { ОЛТАР }{ }^{\circledR} \text { табл. } 6 \text { мг №30, А. Менаріні Манусрактурінг Логістікс } \\
\text { енд Сервісес С.р.Л., Індія/ІІалія/Італія }\end{array}$ & $2 \mathrm{Mr}$ & 277,75 & 3,09 \\
\hline \multicolumn{5}{|c|}{ Бігуаніди } \\
\hline \multirow[t]{6}{*}{ Метсрормін } & ДІАФОРМІН ${ }^{\circledR}$ табл. 500 мг №60, ПАТ "Фармак", Україна & $2000 \mathrm{Mr}$ & 45,11 & 3,01 \\
\hline & $\begin{array}{l}\text { ГЛЮКОФАЖ XR табл. пролонг. дії } 500 \text { мг №60, Мерк Санте, } \\
\text { Франція }\end{array}$ & $2000 \mathrm{Mr}$ & 226,73 & 15,11 \\
\hline & $\begin{array}{l}\text { ІНСУФОР табл. } 850 \text { мг №30, Ілко Ілач Сан. ве Тідж. А.Ш., } \\
\text { Туреччина }\end{array}$ & $2000 \mathrm{Mr}$ & 20,40 & 1,60 \\
\hline & СІОФОР ${ }^{\circledR}$ табл. 850 мг №60, БЕРЛІН-ХЕМІ АГ, Німеччина & $2000 \mathrm{Mr}$ & 192,07 & 7,53 \\
\hline & $\begin{array}{l}\text { ІНСУФОР табл. } 1000 \text { мг №30, Ілко Ілач Сан. ве Тідж. А.Ш., } \\
\text { Туреччина }\end{array}$ & $2000 \mathrm{мг}$ & 25,48 & 1,70 \\
\hline & $\begin{array}{l}\text { ГЛЮКОФАЖ XR табл. пролонг. дії } 1000 \text { мг №60, Мерк Санте, } \\
\text { Франція }\end{array}$ & $2000 \mathrm{Mr}$ & 349,28 & 11,64 \\
\hline \multicolumn{5}{|c|}{ Інгібітори а-глюкозидази } \\
\hline \multirow[t]{2}{*}{ Воглібоза } & ВОКСИД ${ }^{\circledR}$ табл. 0,2 мг № 30, ТОВ "КУСУМ ФАРМ", Україна & $0,3 \mathrm{мг}$ & 53,06 & 2,65 \\
\hline & ВОКСИД ${ }^{\circledR}$ табл. 0,3 мг № 30, ТОВ "КУСУМ ФАРМ", Україна & 0,3 мг & 62,49 & 2,08 \\
\hline \multicolumn{5}{|c|}{ Інгібітори DPP-4 } \\
\hline \multirow[t]{3}{*}{ Ситагліптин } & ЯНУВІЯ табл. 25 мг № 28, Мерк Шарп і Доум Б.В., Нідерланди & 100 мг & 781,19 & 111,60 \\
\hline & ЯНУВІЯ табл. 50 мг №28, Мерк Шарп і Доум Б.В., Нідерланди & $100 \mathrm{Mr}$ & 738,18 & 52,73 \\
\hline & $\begin{array}{l}\text { ЯНУВІЯ табл. } 100 \text { мг № 28, Мерк Шарп і Доум Б.В., } \\
\text { Нідерланди }\end{array}$ & 100 мг & 992,22 & 35,44 \\
\hline
\end{tabular}

ISSN 2312-0967. Pharmaceutical review. 2017. № 3 
Фармацевтичний менеджмент, маркетинг та логістика

Pharmaceutical management, marketing and logistics

Продовження табл. 2

\begin{tabular}{|c|c|c|c|c|}
\hline 1 & 2 & 3 & 4 & 5 \\
\hline \multirow[t]{2}{*}{ Саксагліптин } & $\begin{array}{l}\text { ОНГЛІЗА табл. 2,5 мг № 30, Брістол-Майєрс Сквібб Компані, } \\
\text { США }\end{array}$ & $5 \mathrm{Mr}$ & 560,63 & 37,38 \\
\hline & $\begin{array}{l}\text { ОНГЛІЗА табл. } 5 \text { мг № 30, Брістол-Майєрс Сквібб Компані, } \\
\text { США }\end{array}$ & $5 \mathrm{Mr}$ & 548,71 & 18,29 \\
\hline \multicolumn{5}{|c|}{ Інгібітори SGLT2 } \\
\hline Дапагліфрлозин & $\begin{array}{l}\text { ФОРКСІГА табл. } 10 \text { мг № 30, Брістол-Майєрс Сквібб Компані, } \\
\text { США }\end{array}$ & $10 \mathrm{Mr}$ & 727,26 & 24,24 \\
\hline \multicolumn{5}{|c|}{ Меглітиніди } \\
\hline \multirow[t]{2}{*}{ Репаглінід } & НОВОНОРМ ${ }^{\circledR}$ табл. 1 мг № 30, А/Т Ново Нордіск, Данія & $4 \mathrm{Mr}$ & 223,94 & 29,86 \\
\hline & НОВОНОРМ ${ }^{\circledast}$ табл. 2 мг № 30, А/Т Ново Нордіск, Данія & $4 \mathrm{Mr}$ & 315,98 & 21,07 \\
\hline \multicolumn{5}{|c|}{ Тіазолідиндіони } \\
\hline \multirow[t]{3}{*}{ Піоглітазон } & ГЛЮТАЗОН ${ }^{\circledR}$ табл. 15 мг № 28, ТОВ "КУСУМ ФАРМ", Україна & $30 \mathrm{Mr}$ & 113,60 & 8,11 \\
\hline & ГЛЮТАЗОН ${ }^{\circledR}$ табл. 30 мг № 28, ТОВ "КУСУМ ФАРМ", Україна & $30 \mathrm{Mr}$ & 171,31 & 6,12 \\
\hline & ГЛЮТАЗОН ${ }^{\circledR}$ табл. 45 мг № 28, ТОВ "КУСУМ ФАРМ", Україна & $30 \mathrm{Mr}$ & 238,52 & 5,68 \\
\hline \multicolumn{5}{|c|}{ Комбіновані препарати } \\
\hline \multirow{4}{*}{$\begin{array}{l}\text { Метфрормін + } \\
\text { глібенкламід }\end{array}$} & ГЛІБОФОР ${ }^{\circledR}$ табл. 500 мг/5мг № 60, ПАТ "Фармак", Україна & 2 табл. & 181,58 & 6,05 \\
\hline & $\begin{array}{l}\text { ГЛІБОМЕТ } \\
\text { Німеччина }\end{array}$ & 2 табл. & 131,98 & 6,60 \\
\hline & ГЛЮКОВАНС табл. 500 мг/2,5 мг № 30, Мерк Санте, Франція & 2 табл. & 109,59 & 7,31 \\
\hline & ГЛЮКОВАНС табл. 500 мг/5 мг № 30, Мерк Санте, Франція & 2 табл. & 120,56 & 8,04 \\
\hline \multirow[t]{4}{*}{$\begin{array}{l}\text { Метфрормін + } \\
\text { глімепірид }\end{array}$} & $\begin{array}{l}\text { ДУГЛИМАКС }{ }^{\circledR} \text { табл. } 500 \text { мг/1 мг № 60, ТОВ "КУСУМ ФАРМ", } \\
\text { Україна }\end{array}$ & 2 табл. & 129,31 & 4,31 \\
\hline & $\begin{array}{l}\text { ДУГЛИМАКС }{ }^{\circledR} \text { табл. } 500 \text { мг/2 мг № 60, ТОВ "КУСУМ ФАРМ", } \\
\text { Україна }\end{array}$ & 2 табл. & 181,08 & 6,04 \\
\hline & $\begin{array}{l}\text { АМАРИЛ® М табл. } 500 \text { мг/2 мг № 30, Хендок Інк., Республіка } \\
\text { Корея }\end{array}$ & 2 табл. & 113,37 & 7,56 \\
\hline & $\begin{array}{l}\text { АМАРИЛ® М СР табл. } 500 \text { мг/2 мг № 30, Хендок Інк., } \\
\text { Республіка Корея }\end{array}$ & 2 табл. & 176,54 & 11,77 \\
\hline $\begin{array}{l}\text { Метср ормін + } \\
\text { гліклазид }\end{array}$ & $\begin{array}{l}\text { ДІАНОРМ-М табл. } 500 \text { мг/80 мг № 60, Мікро Лабс Лімітед, } \\
\text { Індія }\end{array}$ & 2 табл. & 214,29 & 7,14 \\
\hline \multirow[t]{3}{*}{$\begin{array}{l}\text { Меторормін + } \\
\text { ситагліптин }\end{array}$} & $\begin{array}{l}\text { ЯНУМЕТ табл. } 500 \text { мг/50 мг №56, Мерк Шарп і Доум Ідеа Інк, } \\
\text { Швейцарія }\end{array}$ & 2 табл. & 805,14 & 28,76 \\
\hline & $\begin{array}{l}\text { ЯНУМЕТ табл. } 850 \text { мг/50 мг №56, Мерк Шарп і Доум Ідеа Інк, } \\
\text { Швейцарія }\end{array}$ & 2 табл. & 784,72 & 28,03 \\
\hline & $\begin{array}{l}\text { ЯНУМЕТ табл. } 1000 \text { мг/50 мг №56, Мерк Шарп і Доум Ідеа } \\
\text { Інк, Швейцарія }\end{array}$ & 2 табл. & 815,50 & 29,13 \\
\hline \multirow[t]{3}{*}{$\begin{array}{l}\text { Меторормін + } \\
\text { саксагліптин }\end{array}$} & $\begin{array}{l}\text { КОМБОГЛІЗА XR табл. } 1000 \text { мг/2,5 мг № 28, АстраЗенека, } \\
\text { Великобританія }\end{array}$ & 1 табл. & 490,65 & 17,52 \\
\hline & $\begin{array}{l}\text { КОМБОГЛІЗА XR табл. } 500 \text { мг/5 мг № 28, АстраЗенека, } \\
\text { Великобританія }\end{array}$ & 1 табл. & 717,94 & 25,64 \\
\hline & $\begin{array}{l}\text { КОМБОГЛІЗА XR табл. } 1000 \text { мг/5 мг № 28, АстраЗенека, } \\
\text { Великобританія }\end{array}$ & 1 табл. & 766,08 & 27,36 \\
\hline $\begin{array}{l}\text { Глімепірид+ } \\
\text { піоглітазон + } \\
\text { меторормін }\end{array}$ & $\begin{array}{l}\text { ТРИПРАЙД табл. } 2 \text { мг/15 мг/500 мг № 30, Мікро Лабс } \\
\text { Лімітед, Індія }\end{array}$ & 2 табл. & 205,55 & 13,70 \\
\hline
\end{tabular}

Примітки: - DDD для мікронізованої фрорми субстанції глібенкламіду;

** - DDD для лікарських фрорм гліклазиду з модифрікованим вивільненням.

ISSN 2312-0967. Фармацевтичний часопис. 2017. № 3 
Встановлено, що вартість DDD синтетичних ПЦЗ коливається від 0,55 до 111,60 грн. Для наочної оцінки економічної доступності різних класів синтетичних ПЦЗ було здійснено графрічний аналіз шляхом побудови «вартісного коридору» - області, що утворена між графріками мінімальної та максимальної вартостей DDD усередині кожного з класів ПЦЗ, включно їх різні комбінації (рис. 4). Згідно з даними літератури доступними вважають препарати, витрати на які не перевищують $10 \%$ від доходів пацієнтів [16]. Було визначено, що на період дослідження (березень 2017 року) прожитковий мінімум в Україні склав 1544 грн, а середньомісячна нарахована заробітна плата - 6752 грн [17]. У зв'язку з цим на графріку у вигляді прямих ліній відмічали межі на рівні 10 \% від величин прожиткового мінімуму та середньомісячної заробітної плати, розділених на 31 (кількість календарних днів у березні) - 4,98 грн та 21,78 грн відповідно.

Як видно 3 даних рисунка 4, найменш доступними $€$ препарати інгібіторів DPP-4, інгібіторів SGLT-2, меглітинідів та комбінацій метформіну із інгібіторами DPP-4: мінімальні вартості DDD для цих класів знаходиться майже на рівні або вище межі економічної доступності, розрахованої на основі середньомісячної заробітної плати. До економічно доступних для всіх верств населення, включно соціально незахищені верстви із мінімальним місячним доходом, можна віднести лише препарати похідних сульфранілсечовини, бігуанідів та їх комбінацій - їх «вартісний коридор» починається нижче межі економічної доступності за прожитковим мінімумом. «Вартісний кори- дор» інгібіторів $\alpha$-глюкозидази, тіазолідиндіонів та комбінацій метформіну із похідним сульфонілсечовини і тіазолідиндіоном знаходиться між зазначеними межами доступності, отже, препарати цих класів $€$ доступними для споживачів, що мають місячний дохід вище прожиткового мінімуму.

Подальшим етапом нашої роботи був аналіз асортименту та доступності наявних на фрармацевтичному ринку України лікарських засобів рослинного походження для застосування в терапії ЦД 2 типу. Одержані дані представлені у таблиці 3.

Як видно з представлених у таблиці 3 даних, препарати рослинного походження гіпоглікемічної дії представлені на фрармацевтичному ринку України в дуже обмеженій кількості. Крім того, більшість з них пропонують у вигляді лікарських зборів, застосування яких $€$ не завжди зручним порівняно з твердими дозованими формами. 3 іншого боку, рослинні препарати вітчизняного виробництва здебільшого виробляються на основі сировини, що може заготовлюватися на території України, а тому є економічно доступними.

Отже, на даний момент на фрармацевтичному ринку України не вистачає лікарських засобів рослинного походження із гіпоглікемічною дією, зокрема у вигляді твердих дозованих фрорм. Тому розробка нового лікарського препарату для лікування ЦД 2 типу на основі рослинної сировини вітчизняного походження, що може використовуватись як монотерапія (на початкових стадіях захворювання) або у комбінації із синтетичними ПЦЗ, є перспективним напрямком.

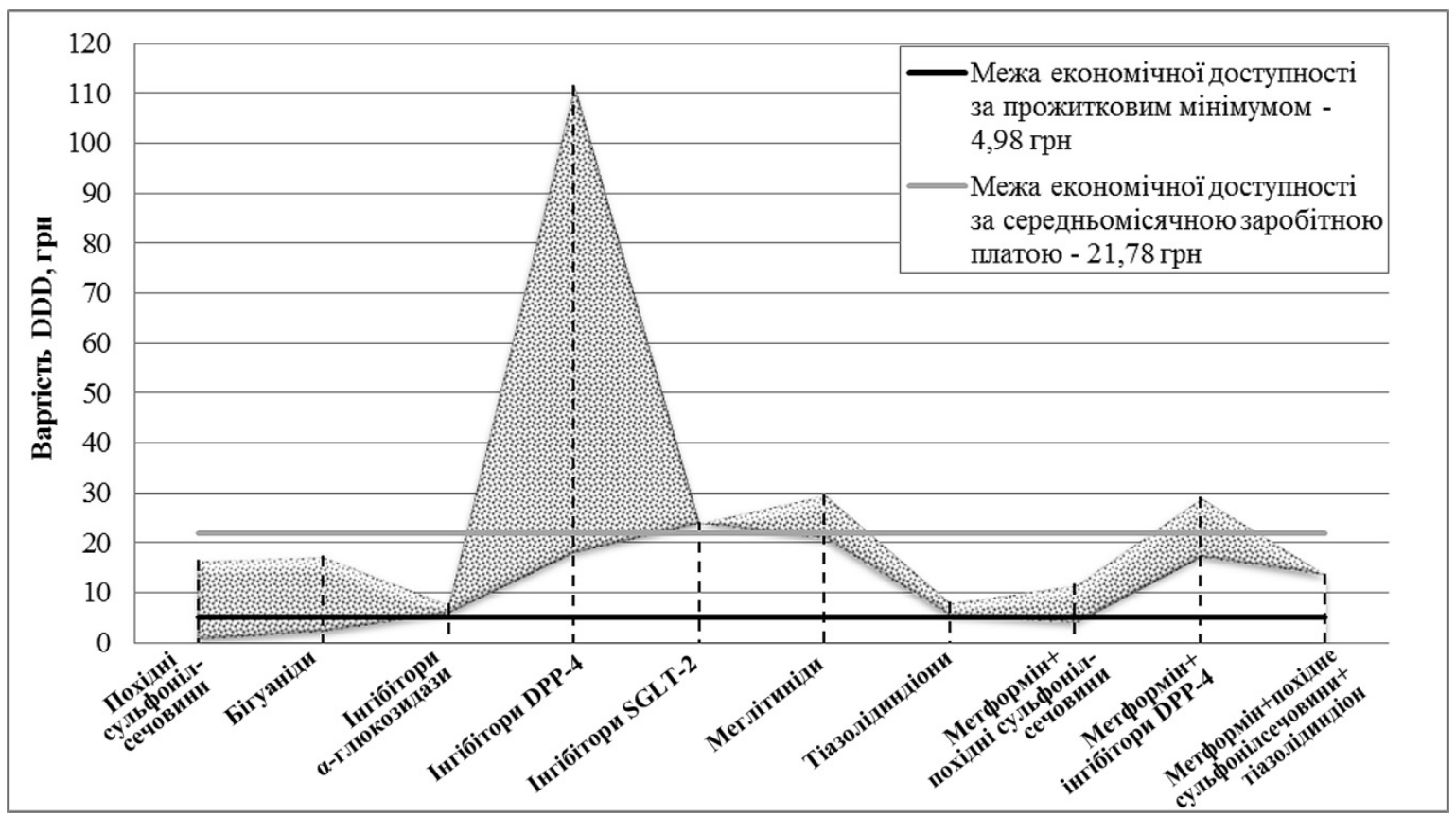

Рис. 4. Графрічний аналіз економічної доступності різних класів синтетичних пероральних цукрознижувальних засобів шляхом побудови «вартісного коридору».

ISSN 2312-0967. Pharmaceutical review. 2017. № 3 
Фармацевтичний менеджмент, маркетинг та логістика

Pharmaceutical management, marketing and logistics

Таблиця 3. Рослинні лікарські засоби із гіпоглікемічною дією, наявні на фрармацевтичному ринку України

\begin{tabular}{|c|c|c|c|c|}
\hline $\begin{array}{c}\text { Торгове } \\
\text { найменування }\end{array}$ & Форма випуску & $\begin{array}{c}\text { Склад активних } \\
\text { компонентів }\end{array}$ & Виробник & $\begin{array}{c}\text { Середньозважена } \\
\text { роздрібна вартість, } \\
\text { грн }\end{array}$ \\
\hline Гуарем & $\begin{array}{c}\text { гранули по } 5 \text { г у } \\
\text { пакетах № } 30 \\
\end{array}$ & смола гуарова & $\begin{array}{c}\text { Оріон Корпорейшн, } \\
\text { Фінляндія } \\
\end{array}$ & 523,39 \\
\hline $\begin{array}{l}\text { Квасолі стулки } \\
\text { плодів }\end{array}$ & $\begin{array}{l}\text { стулки плодів по } \\
50 \text { г, } 60 \text { г у пачках }\end{array}$ & квасолі стулки плодів & $\begin{array}{c}\text { ПрАТ "Ліктрави", } \\
\text { Україна }\end{array}$ & 9,03 \\
\hline Чорниці пагони & $\begin{array}{c}\text { пагони по } 75 \text { г у } \\
\text { пачках, по 1,5 г } \\
\text { у фрільтр-пакетах } \\
\text { № } 20 \text { у пачках } \\
\end{array}$ & чорниці пагони & $\begin{array}{c}\text { ПрАТ "Ліктрави", } \\
\text { Україна }\end{array}$ & 17,02 \\
\hline Арсразетин & $\begin{array}{c}\text { збір по } 50 \text { г, } \\
\text { 75г або } 100 \text { г у } \\
\text { пачках; по 1,5 г } \\
\text { у фрільтр-пакетах } \\
\text { № } 20 \text { у пачках }\end{array}$ & $\begin{array}{c}\text { чорниці пагони, } \\
\text { квасолі стулки плодів, } \\
\text { елеутерококу колючого } \\
\text { кореневища і корені, } \\
\text { шипшини плоди, хвоща } \\
\text { польового трава, звіробою } \\
\text { трава, ромашки квітки }\end{array}$ & $\begin{array}{l}\text { ПрАТ "Ліктрави", } \\
\text { Україна; } \\
\text { ПрАТ } \\
\text { Фармацевтична } \\
\text { фрабрика "Віола", } \\
\text { Україна }\end{array}$ & 17,06 \\
\hline Садифіт & $\begin{array}{c}\text { збір по } 75 \text { г у } \\
\text { пачках; по 3,0 г } \\
\text { у фрільтр-пакетах } \\
\text { № } 20 \text { у пачках }\end{array}$ & $\begin{array}{c}\text { топінамбуру бульби, стевії } \\
\text { листя, чорниці пагони, } \\
\text { квасолі стулки плодів, чай } \\
\text { зелений, м'яти перцевої } \\
\text { листя }\end{array}$ & $\begin{array}{c}\text { ПрАТ "Ліктрави", } \\
\text { Україна }\end{array}$ & 26,66 \\
\hline $\begin{array}{l}\text { Протидіабетичний } \\
\text { збір }\end{array}$ & $\begin{array}{c}\text { збір по } 2 \text { г у } \\
\text { орільтр-пакетах } \\
\text { № } 25 \text { в пачках; } \\
\text { по } 50 \text { г у пакетах; } \\
\text { по } 50 \text { г у пакеті } 3 \\
\text { плівки у пачках }\end{array}$ & $\begin{array}{c}\text { розторопші плоди, цикорію } \\
\text { корені, брусниці листя, } \\
\text { кукурудзи стовпчики з } \\
\text { приймочками, споришу } \\
\text { трава, льону насіння }\end{array}$ & $\begin{array}{c}\text { ПАТ "Лубнифрарм", } \\
\text { Україна }\end{array}$ & 11,25 \\
\hline
\end{tabular}

Висновки. 1. Проведений порівняльний аналіз встановив, що асортимент різних класів синтетичних ПЦЗ, представлених на фрармацевтичному ринку України, є вкрай неоднаковим. Широко представленими як іноземними, так і вітчизняними виробниками $€$ препарати бігуанідів та похідних сульфонілсечовини. Препарати інших класів синтетичних ПЦЗ репрезентовані у значно менше.

2. Неоднаковою також $€$ економічна доступність різних класів ПЦЗ. Найдоступнішими є препарати похідних сульфанілсечовини, бігуанідів та їх комбінацій. Інші класи віднесені до таких, що доступні лише для споживачів із місячним доходом вище прожитко- вого мінімуму, або недоступних для більшої частини населення України.

3. Асортимент лікарських препаратів рослинного походження на вітчизняному фрармацевтичному ринку $є$ досить обмеженим, більшість з них виробляють у формі лікарських зборів. В той же час, в якості сировини для рослинних препаратів вітчизняного виробництва використовують здебільшого види рослин, які можна заготовлювати на території України, а тому ці препарати є економічно доступними. Таким чином, розробка нового засобу на рослинній основі у твердій дозованій фрормі для лікування цукрового діабету другого типу є перспективним напрямком вітчизняної фрармації.

\section{МАРКЕТИНГОВОЕ ОБОСНОВАНИЕ ЦЕЛЕСООБРАЗНОСТИ РАЗРАБОТКИ НОВОГО ЛЕКАРСТВЕННОГО ПРЕПАРАТА НА РАСТИТЕЛЬНОЙ ОСНОВЕ ДЛЯ ЛЕЧЕНИЯ САХАРНОГО ДИАБЕТА ВТОРОГО ТИПА}

\section{Т. Е. Колиснык, Е. А. Рубан, А. Б. Ольховская}

Национальный фрармацевтический университет, Харьков

kolisnyktatyana@gmail.com

Цель работы. Обосновать в контексте маркетинга целесообразность создания нового фрармацевтического препарата на основе субстанции растительного происхождения для лечения сахарного диабета второго типа.

ISSN 2312-0967. Фармацевтичний часопис. 2017. № 3 
Материалы и методы. В работе использованы маркетинговый метод, методы мониторинга, логического обобщения, группировки и графический метод исследования.

Результаты и обсуждение. Проведен сравнительный анализ ассортимента и экономической доступности пероральных сахароснижающих средств синтетического и растительного происхождения, представленных на фармацевтическом рынке Украины. Установлено, что наиболее широкими ассортиментом и экономической доступностью среди синтетических средств характеризуются препараты бигуанидов и производных сульфонилмочевины. По сравнению с синтетическими средствами лекарственные препараты растительного происхождения являются более доступными, однако их ассортимент очень ограничен.

Выводы. По результатам проведенных исследований обоснована перспективность разработки нового отечественного препарата на растительной основе в твердой дозированной форме для лечения сахарного диабета второго типа.

Ключевые слова: маркетинговые исследования; сахарный диабет второго типа; пероральные сахароснижающие средства; фрармацевтический рынок Украины.

\section{MARKETING RATIONALE FOR THE EXPEDIENCY OF THE DEVELOPMENT OF A NEW PLANT-BASED MEDICINAL PREPARATION FOR TYPE TWO DIABETES MELLITUS TREATMENT}

\section{T. Ye. Kolisnyk, O. A. Ruban, A. B. Olkhovska}

National University of Pharmacy, Ukraine

kolisnyktatyana@gmail.com

The aim of the work. Rationalizing in the context of marketing the expediency of the development of a new plant-based medicinal preparation for type two diabetes mellitus treatment.

Materials and Methods. The marketing method, methods of monitoring, logical generalization, grouping and graphical method of investigation were used in this work.

Results and Discussion. A comparative analysis of the assortment and economic availability of oral hypoglycemic drugs of synthetic and vegetable origin presented on the pharmaceutical market of Ukraine has been conducted. It has been found that among synthetic drugs biguanides and sulfonylureas are characterized by the broadest assortment and economic availability. Compared with synthetic drugs, plant-based medicines are more affordable, but their assortment is very limited.

Conclusions. According to the results of the research which has been carried out the prospects for the development of a new domestic plant-based medicinal preparation in a solid dosage form for type two diabetes mellitus treatment are rationalized.

Key words: marketing research; type two diabetes mellitus; oral hypoglycemic drugs; pharmaceutical market of Ukraine.

\section{Список літератури}

1. Diagnosis and Classification of Diabetes Mellitus / American Diabetes Association // Diabetes Care. - 2009. Vol. 32(Suppl. 1). - P. S62-S67.

2. International Diabetes Federation, Diabetes Atlas, 7th ed. / Brussels, Belgium: International Diabetes Federation, 2015 [Електронний ресурс]. - Режим доступу: https://www.idf. org/e-library/epidemiology-research/diabetes-atlas.html.

3. Центр медичної статистики Міністерства охорони здоров'я України. Українська база медико-статистичної інфрормації [Електронний ресурс]. - Режим доступу: http://medstat.gov.ua/ukr/news.html.

4. Wilcox G. Insulin and Insulin Resistance / G. Wilcox // The Clinical biochemist. Reviews. - 2005. - Vol. 26(2). P. 19-39.

5. Systematic review: comparative effectiveness and safety of oral medications for type 2 diabetes mellitus / S. Bolen, L. Feldman, J. Vassy [et al.] // Annals of Internal Medicine. - 2007. - Vol. 147(6). - P. 386-399.
6. Comparative effectiveness and safety of medications for type 2 diabetes: an update including new drugs and 2-drug combinations / W. L. Bennett, N. M. Maruthur, S. Singh [et al.] // Annals of Internal Medicine. - 2011. - Vol. 154(9). P. 602-613.

7. Паньків В. І. Безпечність та клінічна ефективність застосування комбінованого препарату метформіну пролонгованої дії та глімепіриду / В. І. Паньків // Международный эндокринологический журнал. - 2013. - № 3. - C. 25-29.

8. Tiwari P. Recent trends in therapeutic approaches for diabetes management: a comprehensive update / P. Tiwari // Journal of Diabetes Research. - 2015. - Vol. 2015. P. 1-11. - DOI: 10.1155/2015/340838.

9. Prabhakar P. K. Synergistic effect of phytochemicals in combination with hypoglycemic drugs on glucose uptake in myotubes / P. K. Prabhakar, M. Doble // Phytomedicine. 2009. - Vol. 16. - P. 1119-1126.

ISSN 2312-0967. Pharmaceutical review. 2017. № 3 
Фармацевтичний менеджмент, маркетинг та логістика Pharmaceutical management, marketing and logistics

10. Державний реєстр лікарських засобів України [Електронний ресурс]. - Режим доступу: http://www.drlz.kiev.ua.

11. Компендиум. Лекарственные препараты [Електронний ресурс]. - Режим доступу: http://compendium.com.ua.

12. GeoApteka [Електронний ресурс]. - Режим доступу: https://geoapteka.com.ua.

13. Tabletki.ua [Електронний ресурс]. - Режим доступу: https://tabletki.ua.

14. Программный комплекс «Аптека». Оптовые предложения [Електронний ресурс]. - Режим доступу: http://pharmbase.com.ua/poisk1.

\section{References}

1. American Diabetes Association. Diagnosis and classification of diabetes mellitus. Diabetes Care. 2010;33(Suppl.1): S62-9. Available from: https://www.ncbi.nlm.nih. gov/pmc/articles/PMC2797383/pdf/zdcS62.pdf.

DOI: 10.1155/2015/340838. [Accessed March 2017].

2. International Diabetes Federation. IDF Diabetes Atlas, 7th edn. [Electronic resource]. Brussels, Belgium: International Diabetes Federation, 2015. Available from: https:// www.idf.org/e-library/epidemiology-research/diabetes-atlas.html. [Accessed March 2017].

3. Center for Health Statistics Ministry of Health of Ukraine. Ukrainian Medical and Statistical Information Base [Electronic resource, Ukrainian]. Available from: http://medstat. gov.ua/ukr/news.html. [Accessed March 2017].

4. Wilcox G. Insulin and insulin resistance. Clin. Biochem. Rev. 2005;26(2):19-39.

5. Bolen S, Feldman L, Vassy J, Wilson L, Yeh HC, Marinopoulos $S$, et al. Systematic review: comparative effectiveness and safety of oral medications for type 2 diabetes mellitus. Ann Intern Med. 2007;147(6): 386-99.

6. Bennett WL, Maruthur NM, Singh S, Segal JB, Wilson LM., Chatterjee R, et al. Comparative effectiveness and safety of medications for type 2 diabetes: an update including new drugs and 2-drug combinations. Ann Intern Med. 2011;154(9): 602-613. Available from: https://www.ncbi. nlm.nih.gov/pmc/articles/PMC3733115/pdf/nihms484311. pdf. DOI: 10.7326/0003-4819-154-9-201105030-00336. [Accessed March 2017].

7. Pankiv VI. [Safety and clinical efficiency of using combined preparation of metformin extended-release and glimepiride]. Mizhnar. endokryn. zhurnal. 2013;3: 25-9. Ukrainian.

8. Tiwari P. Recent trends in therapeutic approaches for diabetes management: a comprehensive update. J Diabe-
15. WHO Collaborating Centre for Drug Statistics Methodology. ATC/DDD Index 2017 [Електронний ресурс]. - Режим доступу: https://www.whocc.no/atc_ddd_index.

16. Демидова М. А. Сравнительное срармакоэкономическое исследование применения трансдермальных фрорм эстрадиола и прогестерона для интравагинального введения (утрожестана) при лечении женщин с климактерическим синдромом / М. А. Демидова, А. Р. Новицкая // Верхневолжский медицинский журнал. - 2013. - № 1. - С. 30-34.

17. Державна служба статистики України. [Електронний ресурс]. - Режим доступу: http://www.ukrstat.gov.ua.

tes Res. 2015. Available from: https://www.hindawi.com/ journals/jdr/2015/340838. DOI: 10.1155/2015/340838 [Accessed March 2017].

9. Prabhakar PK, Doble M. Synergistic effect of phytochemicals in combination with hypoglycemic drugs on glucose uptake in myotubes. Phytomedicine. 2009;16(12): 1119-26. Available from: https://www.ncbi.nlm.nih.gov/ pubmed/19660925. DOI: 10.1016/j.phymed.2009.05.021. [Accessed March 2017].

10. The State Register of Medicinal Products of Ukraine [Electronic resource, Ukrainian]. Available from: http://www. drlz.kiev.ua. [Accessed March 2017].

11. Compendium. Medicinal Preparations [Electronic resource, Russian]. Available from: http://compendium.com. ua. [Accessed March 2017].

12. GeoApteka [Electronic resource, Russian]. Available from: https://geoapteka.com.ua. [Accessed March 2017]. 13. Tabletki.ua [Electronic resource, Russian]. Available from: https://tabletki.ua. [Accessed March 2017].

14. Program complex "Apteka". Wholesale offers [Electronic resource, Russian]. Available from: http://pharmbase. com.ua/poisk1. [Accessed March 2017].

15. WHO Collaborating Centre for Drug Statistics Methodology. ATC/DDD Index 2017 [Electronic resource]. Available from: https://www.whocc.no/atc ddd index. [Accessed March 2017].

16. Demidova MA, Novitskaya AR. [Comparative pharmacoeconomic study of using transdermal forms of estradiol and progesterone for intravaginal introduction (utrogestan) in the treatment of women with climacteric syndrome]. Verkhnevolzhskiy med. zhurn. 2013;1: 30-4. Russian.

17. State Statistics Service of Ukraine [Electronic resource, Ukrainian]. Available from: http://www.ukrstat.gov.ua. [Accessed March 2017]. 